\title{
Chemical Composition and Source Identification of Fine Particulate Matter (PM2.5) in Two Contrastive Areas of Lagos Megacity, Southern Nigeria
}

\author{
James M. Okuo ${ }^{1} \quad$ Faith O. Oyibo $^{1} \quad$ Bala Anegbe $^{2} \quad$ Emmanuel I. Chiedu $^{3} \quad$ Ufuoma Ugbune $^{4}$ \\ 1.Environmental Analytical Research Laboratory, Department of Chemistry, University of Benin, Benin City \\ 2.Department of Basic and Industrial Chemistry, Western Delta University, P.M.B. 10, Oghara, Delta State \\ 3.Department of Production, Analytical and Laboratory Management, Federal Institute of Industrial Research \\ Oshodi, Lagos State, Nigeria \\ 4.Department of Chemistry, Delta State College of Education, Mosogar, Nigeria
}

\begin{abstract}
Industrial activities contribute immensely to high emission rates of particulate matter (PM) and other pollutants into the ambient air. The siting of industrial plants close to a populated area can have adverse implications on human health and the environment at large. The industrialization and urbanization of Lagos megacity, has led to increased pressure on the city especially on air quality. The chemical complexity of airborne particles makes it imperative to consider their composition and sources of emission. This paper deals with the assessment of particulate matter pollution in an industrial and a non industrial area of Lagos State. Samples of $\mathrm{PM}_{2.5}$ were collected with an air sampler (Airmetric model 5.0) between November 2018 and April 2019. Elemental analysis was carried out using Atomic Absorption Spectroscopy (AAS). Particulate mass loading obtained was in the range of 51.28 to $190.48 \mu \mathrm{g} / \mathrm{m}^{3}$ and 41.67 to $88.89 \mu \mathrm{g} / \mathrm{m}^{3}$ in the industrial and control area respectively. Enrichment factor (EF) and principal component Analysis (PCA) were used for source identification. The EF analysis revealed that; $\mathrm{Pb}, \mathrm{Cd}, \mathrm{Cu}, \mathrm{Ni}$ and $\mathrm{Na}$ were severely enriched while $\mathrm{K}$ and $\mathrm{Ca}$ were moderately enriched in virtually all the sites. The result of the PCA showed that the major sources of these elements were industrial/vehicular emission, marine, road dust, crustal dust and incineration.
\end{abstract}

Keywords: Fine particulate matter, elemental characterization and source identification.

DOI: $10.7176 /$ JNSR/9-24-03

Publication date: December $31^{\text {st }} 2019$

\section{INTRODUCTION}

Particulate matter (PM) pollution is very severe in emerging mega-cities in Nigeria such as Lagos, Port-Harcourt, Aba, Kano and Abuja. This is due to the increasing industrialization and urbanization in these areas (Offor et al. 2016). In Nigeria, there has been substantial industrial progress most especially in Lagos State with the establishment of many cottage industries over the last three decades (Owoade et al. 2013). About 70\% of the nation's industrial and commercial activities take place in Lagos (Taiwo 2005; Olowoporoku 2007). However, this remarkable industrialization has not been matched with proper planning for the control of environmental pollution problems that usually accompanies such industrial developments (Owoade et al. 2013). Furthermore, particulate load in Nigeria is high because it is located within an intensively burdened aerosol region as a result of transboundary movements of geogenic particles from desert zones of the Sahara and soot/organic carbon load from biomass burning (Offor et al. 2016).

The chemical complexity of airborne particles makes it imperative to consider the composition and sources of selected primary and secondary particulates deemed to be of health concern. Particulates are one of the deadliest forms of air pollution due to their ability to penetrate deep into the lungs and blood streams unfiltered. The main determinant of the health effects of airborne particulates is strongly related to their size and composition (Radojevic $\&$ Bashkin 2007). It is the size that determines where the particulates will settle when inhaled. Fine particulate matter $\left(\mathrm{PM}_{2.5}\right)$ with aerodynamic diameter, $\left.\mathrm{d}_{\mathrm{ae}} \leq 2.5 \mu \mathrm{m}\right)$ which is the respirable fraction of particulates is of most health concern. This is because, once inhaled it can penetrate into the deepest part of the lungs such as the bronchioles or alveoli, accumulate there and cause detrimental health conditions (USEPA 2008). They have been linked to premature mortality, lung cancer, DNA mutations, respiratory and cardiovascular health problems (Sufian 2011). Specific to Nigeria, the severities of particulates health implications in highly industrialized and urbanized cities have been reported (Ifeanyichukwu 2002). It therefore becomes necessary for periodic adequate and up-to-date studies on the level of concentration and sources of ambient airborne PM; especially $\mathrm{PM}_{2.5}$ in the city considering its serious health implications. This would be facilitated by obtaining reliable information about the source-receptor relationship of the pollutants hence the need for this study.

In this study, $\mathrm{PM}_{2.5}$ in an industrial and a non- industrial areas of Lagos State which is a fast growing city with an estimated population of $21,200,000$ people (Oshodi 2013) were collected and characterized by an analytical technique. The data obtained were further subjected to statistical analysis and compared with available regulatory 
standards.

\section{EXPERIMENTAL}

\subsection{Study area}

The receptor sites selected for sampling are: Ikeja and Epe, Lagos State (Fig 1). Ikeja represents a typical industrial axis with a concentration of varying classes of industries. It is the hub of the nation's aviation activities as it handles about 37\% domestic and 74\% international departures (National Bureau of Statistics Annual Bulletin 2010). Epe on the other hand, is typically a non industrial area and lies on the north bank of the coastal Lagos Lagoon. It is a collecting point for the export of agricultural products like fish, cassava, coconuts among others to Lagos State and its environs. The main occupation of the people is fishing. It is the second smallest by population in the State (NigeriaCongress.org 2004). Sites in each industrial were carefully chosen to represent an industrial type in a manner that predominant pollutants emitted by the industries and other commercial activities around the sampling site would be captured.

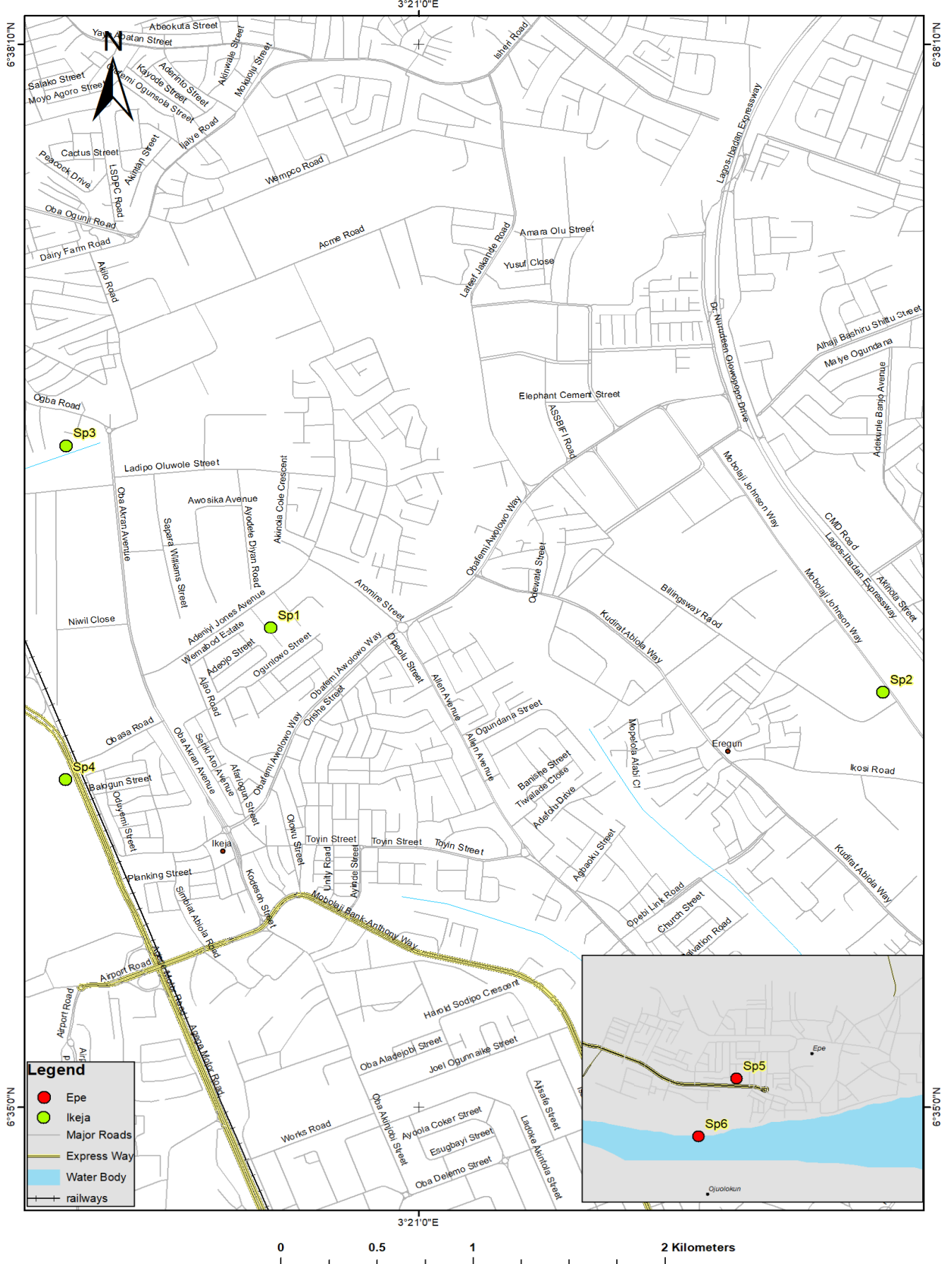

Figure1 Map of Lagos metropolis showing the sampling sites 


\subsection{Sample Collection}

Samples of fine airborne particulate matter $\left(\mathrm{PM}_{2.5}\right)$ were collected on pre weighed filter papers using a portable air sampler (Okuo et al. 2017). A size selective impactor was placed in the cassette holder and was fixed onto the sampler (Airmetric: model 5.0). The filters used for the $\mathrm{PM}_{2.5}$ collection were humidity conditioned in a charged desiccator for 24 hours prior to weighing before and after sampling. Sampling was done in each site once every fortnight between November 2018 and April 2019. Samples were collected at a flow rate of $5 \mathrm{~L} / \mathrm{min}$ for eight hours between 8:00 a.m and 4:00 p.m on each sampling day. A sampling height of about $1.6 \mathrm{~m}$ above ground level which is within the human breathing zone was maintained throughout the sampling period. The sampler was positioned at locations where there was free circulation of air. It was also closely monitored throughout the duration of sampling to ensure accurate sampling collection timing and to prevent vandalism. Metrological parameters were measured concurrently with the particulates with the aid of a thermo-hygrometer. After each sampling, the loaded filter was carefully kept in well-labeled polythene bag in desiccator so that it could equilibrate. Thereafter, it was taken to the laboratory for further sample preparation and analysis.

The concentration of each $\mathrm{PM}_{2.5}$ in $\mu \mathrm{g} / \mathrm{m}^{3}$ collected per the volume of air sampled was obtained by dividing the difference between the filter weight $\left(\mathrm{g}\right.$ ) after and before sampling, $\mathrm{W}_{2}$ and $\mathrm{W}_{1}$, respectively, by the total volume of air sampled, $\mathrm{V}_{\text {air }}$ (flow rate in $\mathrm{m}^{3} / \mathrm{min} \times$ sampling time in seconds)

$\mathrm{PM}_{2.5 \mu \mathrm{g} / \mathrm{m}^{3}}=\frac{\mathrm{W}_{2}-\mathrm{W}_{1}}{\mathrm{Q} \times \mathrm{T}} \times 10^{6} \times 10^{3}$

\subsection{Sample Preparation}

The loaded filter paper was carefully placed inside a $100 \mathrm{ml}$ beaker. $10 \mathrm{ml}$ of $\mathrm{HNO}_{3}$ was added and heated at $150^{\circ} \mathrm{C}$ in a fume cupboard. The sample was intermittently spiked with $5 \mathrm{ml}$ perchloric acid after an hour and was heated for three hours until a clear solution was observed. The digest was cooled, filtered into $100 \mathrm{ml}$ standard volumetric flask and diluted with distilled water to the $\mathrm{ml}$ mark in the $100 \mathrm{ml}$ volumetric flask. A blank sample was prepared in the same manner. Elemental analysis was then carried out on the final digest and the blank using Perkin Elmer A Analyst 400 atomic absorption spectrophotometer. Air-acetylene flame and hollow cathode lamps with background correction were used for the instrumental analysis. The blank concentration was duly subtracted from the obtained concentration. The alkali and alkali-earth metals were analyzed using Sherwood Model 410 Flame Photometer.

\subsection{Pollution Indices (PIs)}

To have a first indication on the extent of the contributions of anthropogenic emissions to atmospheric elemental levels, enrichment factors (EF) were calculated for each element (Yongming 2016; Ayrault 2010; Huang 2010) using the equation below.

$E F=\frac{\left(\frac{E}{R}\right)_{\text {sample }}}{\left(\frac{E}{R}\right)_{\text {crustal }}}$

Where $\mathrm{E}$ is the element of interest and $\mathrm{R}$, the reference material

$\left(\frac{E}{R}\right)_{\text {sample }}$ is the ratio of the element of interest to the reference material in the sample

$\left(\frac{E}{R}\right)_{\text {crustal }}$ is the ratio of the element of interest to the reference material in the crustal material

Fe was used as the reference element in this study because of its crustal abundance. Previous studies that have used $\mathrm{Fe}$ as the reference element include: (Okuo et al. 2017; Okuo et al. 2018; Okuo \& Ndiokwere 2005; Ediagbonya 2012). Other elements popularly used for computing enrichment factor include: $\mathrm{Al}, \mathrm{Li}, \mathrm{Sc}, \mathrm{Ti}, \mathrm{Si}$ and $\mathrm{Zr}$.

Elements with EF next to unity have a strong natural origin while elements with high EF could have anthropogenic origin, or are due to other natural sources such as marine aerosols (Ezeh 2017).

\subsection{Multivariate Analysis of Metals}

To further elucidate relationships among the sampling sites and to identify the probable sources contributing to elemental concentration in the area, the concentrations of the metals analyzed were subjected to statistical analysis. 


\subsubsection{Inter-metallic Correlation Matrix}

Correlation coefficient is a measure of the linear correlation between two variables and is assigned arbitrary values between +1 and -1 . Where 1 is total positive correlation, 0 is no correlation, and -1 is the total negative correlation. It is widely used in the sciences as a measure of the degree of linear dependences between two variables. A Pearson distance correlation matrices of the elements (Sze'kely et al. 2007) was carried out to determine if some metals are correlated with others. This was calculated using Statistical Package for Social Scientist (SPSS) software and correlation was considered significant at the 0.05 level (two tailed). A strong correlation of these metals suggests a common source of emission.

\subsubsection{Source Identification}

In order to identify a probable number of contributing source factors to metals emission at the sampling sites, multivariate factor analysis was adopted (Ogulei et al. 2005; Wang et al. 2008). The elemental concentrations of the fine particulate matter obtained were subjected to factor analysis with varimax rotation and only factors with eigen values $\geq 1$ were considered significant and retained (Huang 2009).

\section{RESULTS AND DISCUSSION}

\subsection{Mass Concentration of Particulate Matter $\mu \mathrm{g} / \mathrm{m}^{3}$}

The $\mathrm{PM}_{2.5}$ mass loadings obtained in the receptor sites ranged from 51.28 to $190.48 \mu \mathrm{g} / \mathrm{m}^{3} \quad$ and 41.67 to 88.89 $\mu \mathrm{g} / \mathrm{m}^{3}$ in the industrial area and control area respectively as against the regulatory limit of $25 \mu \mathrm{g} / \mathrm{m}^{3}$ (WHO 2015). The observed difference in the $\mathrm{PM}_{2.5}$ mass loadings in the various receptor sites may be attributed to the variation in anthropogenic activities in the different receptor sites. Mass concentrations of $\mathrm{PM}_{2.5}$ in this study are within the same range of those reported for urban site in Lagos (Obioh 2005), semi urban site in Osun (Obioh 2005) and rural site in Edo (Ediagbonya 2013).

\subsection{Elemental Concentration and Enrichment Factor}

Trace metals are one of the most toxic components of atmospheric particulates that pose severe health challenges. Interest in trace metals relates primarily to their persistence in the environment, non biodegradability, bioaccumulation and consequently, their potential toxicity.

The elemental concentrations and the resultant enrichment factor (EF) of the elements analysed are depicted in Table 1.

Table 1: Mean Elemental Concentration $\left(\mu \mathrm{gm}^{-3}\right)$ and Enrichment Factor (EF) of PM 2.5 in the Various Sites

\begin{tabular}{|c|c|c|c|c|c|c|c|c|c|c|c|c|}
\hline & \multicolumn{2}{|c|}{ IKJ1 } & \multicolumn{2}{|c|}{ IKJ2 } & \multicolumn{2}{|c|}{ IKJ3 } & \multicolumn{2}{|c|}{ IKJ4 } & \multicolumn{2}{|c|}{ LCA5 } & \multicolumn{2}{|l|}{ LCA6 } \\
\hline & Mean \pm S.D & $\overline{E F}$ & $\operatorname{Mean} \pm$ S.D & $\overline{E F}$ & Mean \pm S.D & EF & Mean \pm S.D & $\overline{E F}$ & $\operatorname{Mean} \pm$ S.D & $\overline{E F}$ & Mean \pm S.D & $\overline{E F}$ \\
\hline $\mathrm{Pb}$ & $1.62 \pm 0.36$ & 2896.36 & $1.36 \pm 0.39$ & 3343.33 & $0.79 \pm 0.64$ & 810.61 & $0.52 \pm 0.26$ & 1157.74 & $0.12 \pm 0.07$ & 196.11 & ND & ND \\
\hline $\mathrm{Cd}$ & $0.83 \pm 0.17$ & 98929.79 & $0.55 \pm 0.40$ & 90139.35 & $0.26 \pm 0.26$ & 17785.60 & $0.48 \pm 0.42$ & 71245.64 & $0.10 \pm 0.09$ & 10925.98 & ND & ND \\
\hline $\mathrm{Ni}$ & $0.62 \pm 0.27$ & 326.03 & $0.43 \pm 0.36$ & 310.91 & $0.31 \pm 0.27$ & 93.56 & $0.61 \pm 0.47$ & 399.45 & $0.22 \pm 0.16$ & 106.05 & $0.31 \pm 0.20$ & 91.18 \\
\hline $\mathrm{Cu}$ & $0.69 \pm 0.54$ & 548.28 & $0.78 \pm 0.53$ & 563.97 & $0.44 \pm 0.22$ & 200.66 & $0.20 \pm 0.12$ & 296.86 & $0.28 \pm 0.12$ & 203.95 & $0.17 \pm 0.15$ & 75.56 \\
\hline $\mathrm{Fe}$ & $1.32 \pm 0.35$ & 1.00 & $0.96 \pm 0.33$ & 1.00 & $2.30 \pm 0.74$ & 1.00 & $1.06 \pm 0.42$ & 1.00 & $1.44 \pm 0.57$ & 1.00 & $2.36 \pm 1.01$ & 1.00 \\
\hline $\mathrm{Ca}$ & $12.05 \pm 1.63$ & 19.50 & $8.78 \pm 5.32$ & 19.53 & $11.78 \pm 3.59$ & 10.94 & $6.63 \pm 2.41$ & 13.36 & $10.40 \pm 2.35$ & 15.43 & $9.63 \pm 3.84$ & 8.72 \\
\hline $\mathrm{K}$ & $24.02 \pm 4.93$ & 32.29 & $9.82 \pm 1.47$ & 18.15 & $17.25 \pm 10.65$ & 13.31 & $8.36 \pm 7.04$ & 14.00 & $24.91 \pm 6.38$ & 23.53 & $26.82 \pm 14.28$ & 20.17 \\
\hline $\mathrm{Na}$ & $27.73 \pm 14.95$ & 103.29 & $19.92 \pm 7.88$ & 102.02 & $22.87 \pm 4.12$ & 48.89 & $35.51 \pm 9.59$ & 164.71 & $49.17 \pm 9.47$ & 167.88 & $58.17 \pm 8.33$ & 121.19 \\
\hline
\end{tabular}

IkJ- Ikeja; LCA- Lagos Control Area

\subsubsection{Elemental Concentration}

The concentrations of the trace metals analysed (Table 1) were considerably high in virtually all the sites except the control site. In location 1, the concentration of the trace metals obtained in decreasing order was: $\mathrm{Pb}>\mathrm{Fe}>\mathrm{Cd}>\mathrm{Cu}>\mathrm{Ni}$. The highest concentration of the trace metals which has stimulated the greatest interest in relation to public health $(\mathrm{Pb})$ was obtained in this location. This may be attributed to the presence of a paint industry/other industrial fumes and vehicular emissions in that area. The use of the metal in paint and varnish production, as anti knocking additives to enhance the octane number of gasoline, probably contributed to the buildup of the metal in the atmosphere. This corroborates a study conducted in Lagos (Okuo et al. 2017) where Pb was reported to be associated with the industrial environment and vehicular emission. The highest concentration of $\mathrm{Cd}$ was also observed in this location. Again, this may be associated with the paint industry as it is used as pigmentation in some industrial paints. The elevated concentration could also have been due to automobile wear and tear/tail pipeline emissions. High concentrations of the trace metals were also observed in the other locations in the study area. This suggests predominantly, anthropogenic sources of emission. Apart from the observed high Fe concentration in the control area, the concentrations of the other trace metals were low. This gives an indication that there is minimal anthropogenic emission in this area. An elevated level of Fe was observed probably because; it is a major component of the earth crust. It is an abundant element found in the earth crust and since most roads are unpaved and poorly maintained in this part of the world, it will not be surprising to measure high concentration in any area most especially in an industrialized and urbanized area like Lagos State.

Of the elements analyzed, the light metals $\mathrm{Na}, \mathrm{K}$ and $\mathrm{Ca}$ were found to be the most abundant metals in both the industrial area and control area. Ca influence in the fine fraction could be due to soil dust which is typical of sub-Saharan African aerosol. While the high concentration of the typical marine aerosol elements ( $\mathrm{Na}$ and $\mathrm{K}$ ) obtained, could be due to high impact of sea spray emission to pollutant load in the State air-shed as it is situated 
along the coast of the Atlantic Ocean. Other probable sources of emission include: road dust and crustal dust. Table 2: Comparison of Elemental Concentration $\left(\mu \mathrm{gm}^{-3}\right)$ with other Studies

\begin{tabular}{|c|c|c|c|c|c|c|}
\hline & This Study & $\begin{array}{l}\text { Lagos, Nigeria } \\
\text { (Owoade et } \\
\text { al.2015) } \\
\end{array}$ & $\begin{array}{l}\text { Lagos, Nigeria } \\
\text { (Okuo et al. } \\
\text { 2017) }\end{array}$ & $\begin{array}{l}\text { Lagos, Nigeria } \\
\text { (Obioh et al. } \\
2005)\end{array}$ & $\begin{array}{l}\text { Ibadan, Nigeria } \\
\text { (Ezeh et al. } \\
\text { 2017) }\end{array}$ & $\begin{array}{l}\text { Kanpur, India } \\
\text { Chakraborty \& } \\
\text { Gupta 2010) } \\
\end{array}$ \\
\hline $\mathrm{Pb}$ & ND-1.62 & 0.011 & ND-0.91 & $1.84-9.58$ & $2.40-6.00$ & $0.19-0.36$ \\
\hline $\mathrm{Cd}$ & ND-0.83 & NI & ND-0.94 & NI & $0.093-0.20$ & $0.01-0.05$ \\
\hline $\mathrm{Ni}$ & $0.22-0.62$ & 0.006 & ND-0.22 & NI & $0.045-0.078$ & $0.08-0.10$ \\
\hline $\mathrm{Cu}$ & $0.17-0.78$ & 0.010 & ND-0.19 & ND-3.21 & $0.036-0.088$ & $0.16-0.24$ \\
\hline $\mathrm{Fe}$ & $0.96-2.36$ & 1.579 & ND-0.81 & NI & $3.0-3.3$ & $0.97-1.24$ \\
\hline $\mathrm{Ca}$ & $6.63-12.05$ & 2.309 & $63-689$ & NI & $0.24-0.72$ & $0.98-2.87$ \\
\hline $\mathrm{K}$ & $8.36-26.82$ & 0.696 & $101-275$ & NI & $1.4-1.7$ & NI \\
\hline $\mathrm{Na}$ & $19.92-58.17$ & 0.538 & $136-662$ & NI & $23-45$ & NI \\
\hline
\end{tabular}

ND- Not Detected; NI- No Information

The concentration of some of the analysed trace metals $\mathrm{Pb}$ and $\mathrm{Cd}$ which are very detrimental to the human health are very pronounced in virtually all the sites. These metals violate the WHO regulatory limit of $0.5 \mu \mathrm{gm}^{-}$ ${ }^{3}$ and $0.005 \mu \mathrm{gm}^{-3}$ respectively (USEPA 2014). These high concentrations are certainly signature of anthropogenic activities.

3.3.2 Enrichment Factor: the EF calculated for the trace metals $(\mathrm{Pb}, \mathrm{Cd}, \mathrm{Ni}$ and $\mathrm{Cu})$ in the various sites show that they are extremely severe enriched. This implies that, the presence of these metals in the air is predominantly from anthropogenic sources. The enrichment of these metals should be due largely to vehicular emission as they are associated with fumes/wear and tear from automobiles. It is most likely that, the presence of $\mathrm{Pb}$ and $\mathrm{Cd}$ in the air is also from other anthropogenic sources apart from vehicular emission since, they showed exceedingly enrichment values. The other sources may include emission from industries such as: paint industry, steel industry e.t.c, public smoking, waste incineration among others. Among the light metals analysed, Na was observed to be more enriched. The high enrichment of the element is probably due to the reason stated above. Though $\mathrm{K}$ and $\mathrm{Ca}$ are enriched, they are not extremely enriched. K may have been released mainly from biomass burning and sea breeze while Ca may have been released from construction activities. Other possible source of the latter metals to the ambient include: crustal dust and road dust.

\subsection{Inter- metallic correlation matrix}

The results of the Pearson inter- metallic correlation matrix for $\mathrm{PM}_{2.5}$ in the industrial area and control area are presented in Tables 3 and 4. The elements $\mathrm{Pb}$ to $\mathrm{Na}$ showed strong/weak and positive/negative correlations.

Table 3: Inter-metallic correlations of $\mathbf{P M}_{2.5}$ in the industrial area samples

\begin{tabular}{lrrrrrrrr} 
& \multicolumn{1}{c}{$\mathrm{Pb}$} & $\mathrm{Cd}$ & $\mathrm{Ni}$ & $\mathrm{Cu}$ & $\mathrm{Fe}$ & $\mathrm{Ca}$ & $\mathrm{K}$ & $\mathrm{Na}$ \\
$\mathrm{Pb}$ & 1.000 & & & & & & & \\
$\mathrm{Cd}$ & $\mathbf{0 . 5 2 7}$ & 1.000 & & & & & & \\
$\mathrm{Ni}$ & 0.348 & $\mathbf{0 . 4 8 0}$ & 1.000 & & & & & \\
$\mathrm{Cu}$ & $\mathbf{0 . 5 9 2}$ & $\mathbf{0 . 6 0 7}$ & 0.349 & 1.000 & & & & \\
$\mathrm{Fe}$ & -0.161 & -0.232 & -0.308 & -0.006 & 1.000 & & & \\
$\mathrm{Ca}$ & 0.178 & 0.377 & 0.104 & $\mathbf{0 . 4 7 3}$ & 0.165 & 1.000 & & \\
$\mathrm{~K}$ & $\mathbf{0 . 5 6 8}$ & 0.131 & 0.339 & 0.300 & 0.263 & 0.138 & 1.000 & \\
$\mathrm{Na}$ & -0.146 & $\mathbf{0 . 4 5 1}$ & $\mathbf{0 . 6 7 7}$ & 0.174 & -0.307 & -0.020 & -0.048 & 1.000 \\
\hline
\end{tabular}

Bolded cells mean that correlation is significant at the 0.05 level (2-tailed).

Table 4: Inter-metallic correlations of $\mathbf{P M}_{2.5}$ in the control area samples

\begin{tabular}{lrrrrrrrr} 
& \multicolumn{1}{c}{$\mathrm{Pb}$} & \multicolumn{1}{c}{$\mathrm{Cd}$} & $\mathrm{Ni}$ & $\mathrm{Cu}$ & $\mathrm{Fe}$ & $\mathrm{Ca}$ & $\mathrm{K}$ & $\mathrm{Na}$ \\
$\mathrm{Pb}$ & $\mathbf{1 . 0 0 0}$ & & & & & & & \\
$\mathrm{Cd}$ & $\mathbf{0 . 5 4 3}$ & $\mathbf{1 . 0 0 0}$ & & & & & & \\
$\mathrm{Ni}$ & $\mathbf{0 . 1 5 5}$ & $\mathbf{- 0 . 2 7 8}$ & $\mathbf{1 . 0 0 0}$ & & & & & \\
$\mathrm{Cu}$ & $\mathbf{0 . 6 3 1}$ & $\mathbf{0 . 3 2 5}$ & $\mathbf{- 0 . 1 1 5}$ & $\mathbf{1 . 0 0 0}$ & & & & \\
$\mathrm{Fe}$ & $\mathbf{- 0 . 2 9 5}$ & $\mathbf{- 0 . 2 8 1}$ & $\mathbf{- 0 . 0 8 3}$ & $\mathbf{0 . 7 9 0}$ & $\mathbf{1 . 0 0 0}$ & & & \\
$\mathrm{Ca}$ & $\mathbf{0 . 2 6 4}$ & $\mathbf{0 . 4 3 9}$ & $\mathbf{0 . 0 1 1}$ & $\mathbf{0 . 1 6 2}$ & $\mathbf{0 . 3 5 5}$ & $\mathbf{1 . 0 0 0}$ & & \\
$\mathrm{K}$ & $\mathbf{- 0 . 4 5 2}$ & $\mathbf{- 0 . 4 4 9}$ & $\mathbf{- 0 . 0 6 1}$ & $\mathbf{0 . 0 3 1}$ & $\mathbf{0 . 1 4 0}$ & $\mathbf{- 0 . 3 8 9}$ & $\mathbf{1 . 0 0 0}$ & \\
$\mathrm{Na}$ & $\mathbf{0 . 1 2 2}$ & $\mathbf{- 0 . 3 1 6}$ & $\mathbf{- 0 . 0 2 0}$ & $\mathbf{- 0 . 1 5 3}$ & $\mathbf{0 . 2 3 8}$ & $\mathbf{- 0 . 2 8 6}$ & $\mathbf{- 0 . 0 1 4}$ & $\mathbf{1 . 0 0 0}$ \\
\hline
\end{tabular}

Bolded cells mean that correlation is significant at the 0.05 level (2-tailed).

In the industrial area, the results of inter-elemental correlation matrix showed that, there is strong correlation between $\mathrm{Pb}$ and $\mathrm{Cd}(\mathrm{r}=0.527), \mathrm{Cu}(\mathrm{r}=0.592), \mathrm{K}(0.568)$; between $\mathrm{Cd}$ and $\mathrm{Ni}(0.480), \mathrm{Cu}(\mathrm{r}=(0.607), \mathrm{Na}(\mathrm{r}=(0.451)$; 
between $\mathrm{Ni}$ and $\mathrm{Na}(\mathrm{r}=0.677)$ and between $\mathrm{K}$ and $\mathrm{Pb}$. Most of these associations are certainly connected with anthropogenic sources of emission. The correlation between $\mathrm{Pb}$ and $\mathrm{Cd}$ may be mainly due to emission from a paint industry, steel industry/other industrial fumes in the area. While that between $\mathrm{Pb}-\mathrm{Cu}$ and $\mathrm{Cu}-\mathrm{Cd}$ may be due to vehicular emission and that between $\mathrm{Ni}$ and $\mathrm{Cd}$ may be from waste burning containing $\mathrm{Ni}-\mathrm{Cd}$ batteries.

\subsection{Principal component analysis (PCA)}

Table 5 and 6 present the PC loadings with eigen values $>1$, explaining more than $74.27 \%$ and $92.74 \%$ of cumulative variance for the industrial and control site respectively. Loadings refer to the coefficients of correlation between individual factor and the elements. A loading close to unity shows that the element is characteristic of that particular source. Communalities of all elements in the data set were in the range of 0.638-0.976 and 0.8520.973 for the industrial and control area respectively. This shows that each element was satisfactorily apportioned to the identified factors.

Table 5: Rotated factor loading for $\mathbf{P M}_{2.5}$ samples in the industrial area

\begin{tabular}{lllll}
\hline Variables & Factor 1 & Factor 2 & Factor 3 & Communality \\
\hline $\mathrm{Pb}$ & - & 0.843 & - & 0.953 \\
$\mathrm{Cd}$ & 0.516 & - & 0.661 & 0.976 \\
$\mathrm{Ni}$ & 0.765 & 0.396 & - & 0.830 \\
$\mathrm{Cu}$ & - & 0.423 & 0.737 & 0.898 \\
$\mathrm{Fe}$ & 0.694 & - & - & 0.916 \\
$\mathrm{Ca}$ & - & - & 0.875 & 0.744 \\
$\mathrm{~K}$ & - & 0.881 & - & 0.952 \\
$\mathrm{Na}$ & 0.849 & - & - & 0.638 \\
Egiene Value & 2.132 & 1.911 & 1.899 & \\
$\%$ Variance & 26.644 & 23.884 & 23.743 & \\
Possible Sources & Marine/ & Vehicular/ & Road dust & \\
& Industrial & Incineration & & \\
\hline
\end{tabular}

Values less than 0.35 are replaced with "-".

Table 6: Table 4: Rotated factor loading for $\mathbf{P M}_{2.5}$ samples in the control area

\begin{tabular}{lllllll}
\hline Variables & Factor 1 & Factor 2 & Factor 3 & Factor 4 & Factor 5 & Communality \\
\hline $\mathrm{Pb}$ & 0.509 & 0.791 & - & - & - & 0.970 \\
$\mathrm{Cd}$ & 0.648 & 0.383 & - & 0.356 & 0.370 & 0.854 \\
$\mathrm{Ni}$ & - & - & - & - & -0.985 & 0.973 \\
$\mathrm{Cu}$ & - & 0.954 & - & - & - & 0.953 \\
$\mathrm{Fe}$ & - & - & 0.942 & - & - & 0.952 \\
$\mathrm{Ca}$ & 0.580 & - & 0.629 & 0.388 & - & 0.903 \\
$\mathrm{~K}$ & -0.915 & - & - & - & - & 0.852 \\
$\mathrm{Na}$ & - & - & - & 0.977 & - & 0.961 \\
Egiene Value & 1.887 & 1.703 & 1.369 & 1.310 & 1.150 & 14.373 \\
\% Variance & 23.548 & 21.293 & 17.116 & 16.373 & Incineration \\
Possible Sources & Road dust & Vehicular & Crustal dust & Marine/ & Resuspension dust &
\end{tabular}

Values less than 0.35 are replaced with "-"

Three major factors were identified in the industrial area. The first factor explained $26.64 \%$ of the variance with high loadings of $\mathrm{Cd}, \mathrm{Ni}, \mathrm{Fe}$ and $\mathrm{Na}$. This factor may represent industrial emission and sea spray. The second factor explained $23.88 \%$ of variance with high loadings of $\mathrm{Pb}, \mathrm{Ni}, \mathrm{Cu}$ and $\mathrm{K}$. This factor may be attributed to vehicular emission/biomass burning. The third factor with high loadings of $\mathrm{Cd}, \mathrm{Cu}$ and $\mathrm{Ca}$ explained $23.74 \%$ of the variance. This may be related to road dust (sum of crustal dust and automobile tail pipeline emission). It is worthy to note that over time, the metals generated from various sources also become part of crustal dust (Suman \& Asim 2014).

In the control area, five factors were identified. Factor 1 loaded on $\mathrm{Pb}, \mathrm{Cd}, \mathrm{Ca}$ and $\mathrm{K}$ and explained $23.55 \%$ of the variance. This source may be attributed to road dust. Factor 2 is loaded primarily by $\mathrm{Pb}, \mathrm{Cd}$, and $\mathrm{Cu}$ and explained $21.29 \%$ of the variance. This may be a signature of vehicular emission. Factor 3 which loaded on $\mathrm{Fe}$ and $\mathrm{Ca}$ and explained $17.12 \%$ of the variance is probably emission from crustal dust. Factor 4 showed high loadings for $\mathrm{Cd}, \mathrm{Ca}$ and $\mathrm{Na}$ at $16.37 \%$ of the variance. This may due to combination of marine and road dust emission. Factor 5 showed high loadings for $\mathrm{Cd}$ and $\mathrm{Ni}$ at $14.37 \%$ of the variance. This may represent incineration. 
Table 7. Elemental Spatial variation

\begin{tabular}{llllllll}
\hline Element & IKJ1 & IKJ2 & IKJ3 & IKJ4 & LCS5 & LCS6 & P \\
\hline $\mathrm{Pb}$ & $1.62 \pm 0.36$ & $1.36 \pm 0.39$ & $0.79 \pm 0.64$ & $0.52 \pm 0.26$ & $0.12 \pm 0.07$ & $\mathrm{ND}$ & 0.000 \\
$\mathrm{Cd}$ & $0.83 \pm 0.17$ & $0.55 \pm 0.40$ & $0.26 \pm 0.26$ & $0.48 \pm 0.42$ & $0.10 \pm 0.09$ & ND & 0.016 \\
$\mathrm{Ni}$ & $0.62 \pm 0.27$ & $0.43 \pm 0.36$ & $0.31 \pm 0.27$ & $0.61 \pm 0.47$ & $0.22 \pm 0.16$ & $0.31 \pm 0.20$ & 0.275 \\
$\mathrm{Cu}$ & $0.69 \pm 0.54$ & $0.78 \pm 0.53$ & $0.44 \pm 0.22$ & $0.20 \pm 0.12$ & $0.28 \pm 0.12$ & $0.17 \pm 0.15$ & 0.053 \\
$\mathrm{Fe}$ & $1.32 \pm 0.35$ & $0.96 \pm 0.33$ & $2.30 \pm 0.74$ & $1.06 \pm 0.42$ & $1.44 \pm 0.57$ & $2.36 \pm 1.01$ & 0.039 \\
$\mathrm{Ca}$ & $12.05 \pm 1.63$ & $8.78 \pm 5.32$ & $11.78 \pm 3.59$ & $6.63 \pm 2.41$ & $10.40 \pm 2.35$ & $9.63 \pm 3.84$ & 0.379 \\
$\mathrm{~K}$ & $24.02 \pm 4.93$ & $9.82 \pm 1.47$ & $17.25 \pm 10.65$ & $8.36 \pm 7.04$ & $24.91 \pm 6.38$ & $26.82 \pm 14.28$ & 0.083 \\
$\mathrm{Na}$ & $27.73 \pm 14.95$ & $19.92 \pm 7.88$ & $22.87 \pm 4.12$ & $35.51 \pm 9.59$ & $49.17 \pm 9.47$ & $58.17 \pm 8.33$ & 0.118 \\
\hline
\end{tabular}

Table 7 describes the spatial variation of the elements at the various locations in this study. There was spatial variability in $\mathrm{Pb}, \mathrm{Cd}$ and $\mathrm{Fe}(\mathrm{P} \leq 0.05)$ while for the other elements, there was no spatial variability $(\mathrm{P} \geq 0.05)$.

Factors responsible for spatial and ambient concentrations of air pollutants which could also be responsible for the trend in this area include: emission strength, emission rate, emission conditions and atmospheric dispersion conditions (Ukpebor et al.).

\section{CONCLUSION}

The results of this study revealed high and relatively low mass loadings of $\mathrm{PM}_{2.5}$ in the industrial and control area. The concentrations of the trace metals were higher in the industrial area than in the control area. However, high concentrations of the light metals were measured in virtually all the sites in both the industrial and control areas. The study also identified combustion activities (industrial/vehicular), marine and road dust as the predominant sources of emission in the industrial area. Whereas, in the control area; marine, road dust, crustal dust, incineration and vehicular sources of emission were identified.

\section{REFERENCES}

Ayrault, S., Senhou, A., Moskura, M. \& Gaudry, A. (2010). Atmospheric Trace Element Concentrations in Total Suspended Particles Near Paris, France. Journal of Atmospheric Environment 44, 3700-3707.

Chakraborty, A.\& Gupta, T. (2010). Chemical Characterization and Source Apportionment of Submicron ( $\left.\mathrm{PM}_{1}\right)$ Aerosol in Kanpur Region, India. Aerosol and Air Quality Research 10, 433-445.

Ediagbonya, T. F., Ukpebor E. E., \& Okieimen, F.E. (2013). Correlation of Meteorological Parameters and Dust Particles Using Scatter Plot in a Rural Community. Ife Journal of Science 15(3), 445-453.

Ediagbonya, T. F., Ukpebor, E. E. \& Okiemien F. E. (2012). Heavy Metal in Respirable and Inhalable Suspended Particulate Matter in Urban Atmosphere. International Journal of Environmental Skeptics and Critics 2(3), $108-117$.

Ezeh , G.C., Obioh, I.B \& Asubiojo, O.I. (2017). Trace Metals and Source Identification of Air-Borne Particulate Matter Pollution in A Nigerian Megacity. Journal of Environmental and Analytical Toxicology 7(3), 463.

Ezeh, G.C., Abiye, O.E. \& Obioh, I.B. (2017). Elemental Analyses and Source Apportionment of PM 2.5 and PM $2.5-$ ${ }_{10}$ Aerosols from Nigerian Urban Cities. Cogent Environmental Science 3(1), 323-376.

Huang, L., Wang, K., Yuan, C.S. \& Wang G. (2010). Study on the Seasonal Variation and Source Apportionment of $\mathrm{PM}_{10}$ in Harbin, China. Aerosol Air Quality Res 10, 86-93.

Huang, S.S., Tu, J., Liu, H.Y., Hua, M., Liao, Q.L., Feng, J.S., Weng, Z.H. \& Huang, G.M. (2009). Multivariate Analysis of Trace Element Concentrations in Atmospheric Deposition in the Yangtze River Delta, East China. Atmos. Environ 43, 5781-5790.

Ifeanyichukwu, G.P. (2002). Modeling of Air Pollution in Industrial Cities: Case study of Lagos, Nigeria, B. Eng Degree Thesis, Department of Chemical Engineering, Federal University of Technology, Minna, Nigeria.

National Bureau of Statistics Annual Bulletin. (2010). The Review of the Nigerian Economy. Federal Republic of Nigeria Official Gazette.

NigeriaCongress.org". Archived from the original on 3 January 2004, Retrieved 1 July 2019.

Obioh, I.B., Olise, F.S., Owoade, O.K. \& H.B. Olaniyi. (2005). Chemical Characterisation of Suspended Particulates Along air Corridors of Motorways in Two Nigerian Cities. Journal of Applied Science. 5, 347350.

Offor, F.I., Adie, G.U. \& Ana, G.R. (2016). Review of Particulate Matter and Elemental Composition of Aerosols at Selected Locations in Nigeria from 1985-2015, Journal of Health \& Pollution 6(10), 1-18.

Ogulei, D., P. Hopke, L. Zhou, P. Paatero, S. Park, \& J. Ondov. (2005). Receptor Modeling for Multiple Time Resolved Species: The Baltimore supersite. Atmos. Environ. 39:3751-3762. doi:10.1016/j.atmosenv.2005.03.012.

Okuo, J. M. \& Ndiokwere, C. L. (2005). Elemental Concentration of Total Suspended Particulate Matter in Relation to Air Pollution in Niger Delta: A Case Study of Warri: Trends in Applied Science Research 1(1), 91-96. 
Okuo, J. M., Chiedu, I. E., Anegbe, B., Oyibo, F. O. \& Ojo, W. (2017). Elemental Characterization and Source Identification of Fine Particulate Matter (PM2.5) in an Industrial Area of Lagos State, Nigeria. Physical Science International Journal 16(2), 1-11.

Okuo, J. M., Oyibo, F. O., Anegbe, B., Chiedu, I. E., Adeniyi, O. \& Ojo, W. (2018). Quantification of Total Suspended Particulates (TSP) and its Elemental Content in Different Micro Environment of a Residential Area of Lagos State, Nigeria. Physical Science International Journal 19(2), 1-18.

Olowoporoku, D. (2007). Air Quality Management in Lagos. Technical report. Bristol: Air Quality Management Centre.

Oshodi, L. ( 2013). Flood management and Governance Structure in Lagos. Nigeria Regions Magazine. 292: 2224. DOI: $10.1080 / 13673882.2013 .10815622$.

Owoade, K.O., Hopke, P.K., Olise, F.S., Ogundele, L.T., Fawole, O.G., Olaniyi, B.H., Jegede, O.O., Ayoola, M.A. \& Bashiru, M.I. (2015). Chemical Compositions and Source Identification of Particulate Matter $\left(\mathrm{PM}_{2.5}\right.$ and $\mathrm{PM}_{2.5-10}$ ) from a Scrap Iron and Steel Smelting Industry Along the Ife-Ibadan Highway, Nigeria 6(1), 107-119.

Owoade, O.K., Fawole, O.G., Olise, F.S., Ogundele, L.T., Olaniyi, H.B., Almeida, M.S., Ho, M.D. \& Hopke, P.K. (2013). Characterization and Source Identification of Airborne Particulate Loadings at Receptor Site-Classes of Lagos Mega-City, Nigeria. Journal of Air Waste Management Association 63, 1026-1035.

Radojevic, M. and Bashkin, V.N. (2007). Practical Environmental Chemistry. The Royal Society of Chemistry, London, UK.

Sufian, M.E. (2011). Airborne particulate matter $\left(\mathrm{PM}_{10}\right)$ composition and its Genotoxicity at Two Pilgrimage Sites in Makkah, Saudi Arabia. Journal Environmental Chemistry 3(4), 93-102.

Suman, G.S. \& Asim, K. P. (2014). Source Apportionment of Respirable Particulate Matter Using Principal Component Analysis - a Case Study from India. Rep Opinion. 6(8), 26-32. (ISSN: 15539873).

Sze'kely, G.J., Rizzo, M.L. \& Bakirov, N.K. (2007). Measuring and Testing Dependence by Correlation of Distances. Ann Statistics 35, 2769-2794.

Taiwo, O. (2005). The Case of Lagos Air Quality Improvement Project. Technical report. Lagos: Lagos Metropolitan Area Transport Authority (LAMATA).

U.S. Environmental Protection Agency (2008). Region 4: Laboratory and Field Operations $-\mathrm{PM}_{2.5}$ Objectives and History.

U.S. Environmental Protection Agency (U.S. EPA). (2014). National Ambient Air Quality Standards (NAAQS), http://epa.gov/air/criteria.html, Accessed in July 2019.

Ukpebor, J. E., Ukpebor, E. E., Kadiri, V. I., Odiase, J. I., Okuo, J. M. \& Ogbeifun, D. (2012). Atmospheric Trace Metal Concentrations in Suspended Particulate Matter (SPM) of a Rural Residential Area in Southern Nigeria. Ife Journal of Science 14(1), 1-14.

W.H.O. (2015) Regional Office for Europe, OECD. Economic Cost of the Health Impact of Air Pollution in Europe: Clean Air, Health and Wealth Copenhagen: W.H.O Regional Office for Europe.

Wang,W.C., K.S. Chem, S.J. Chem, C.C. Lin, J.H. Tsai, C.H. Lai, \& S.K.Wang. (2008). Characteristics and Receptor Modeling of Atmospheric $\mathrm{PM}_{2.5}$ at Urban and Rural Sites in Pingtung, Taiwan. Aerosol Air Quality Res. 8,112-129.

Yongming H, Peixuan D, Junji C, Posmentier ES. (2006). Multivariate Analysis of Heavy Metal Contamination in Urban Dusts of Xi'an, Central China. Journal of Science and Total Environment 355,176-186. 